\title{
UPAYA MENINGKATKAN HASIL BELAJAR MATEMATIKA DENGAN PEMBELAJARAN MATEMATIKA REALISTIK (PMR) UNTUK SISWA KELAS V UPT. SD NEGERI 01 KOTO LAWEH
}

\author{
MARNITA. HM \\ marnita01@gmail.com
}

\begin{abstract}
This study aims to improve mathematics learning outcomes with realistic mathematics learning for students of class V UPT. SD Negeri 01 Koto Laweh by applying realistic mathematics learning. This research design uses a spiral model. This research consists of 4 steps, namely planning, implementing the action, observing, and reflecting. The subjects in this study were all students of class V UPT. SD Negeri 01 Koto Laweh, X Koto District, Tanah Datar Regency, totaling 19 students consisting of 9 male students and 10 female students. This research was conducted in two cycles. The implementation of each cycle is carried out using realistic mathematics learning methods in mathematics learning in fraction material in problem solving. Collecting data in this study using test and observation methods. The research instrument used was a description sheet and student and teacher observation sheets. The data analysis technique used in this study was carried out by using qualitative data analysis techniques and quantitative data analysis. Quantitative data analysis was carried out by calculating the percentage of student learning completeness. Qualitative data analysis was carried out by describing the activities of students and teachers. The results showed that student learning outcomes had increased as seen from the activity of students who had increased from cycle I to cycle II from $67.11 \%$ to $84.54 \%$. Student learning outcomes also increased from cycle I to cycle II so that students could achieve a KKM of 69. Before the action, only 9 students completed or $47.37 \%$ in cycle I, the number of students who completed increased to 13 students or $68,42 \%$ and in cycle II showed that 17 students or $89.47 \%$ had fulfilled the KKM
\end{abstract}

Keywords: PMR. Learning Outcomes, Mathematics

Abstrak: Penelitian ini bertujuan untuk meningkatkan hasil belajar matematika dengan pembelajaran matematika realistik untuk siswa kelas V UPT. SD Negeri 01 Koto Laweh dengan penerapkan pembelajaran matematika realistik. Desain penelitian ini menggunakan model spiral. Penelitian ini terdiri atas 4 langkah yaitu perencanaan, pelaksanaan tindakan, pengamatan, dan refleksi. subjek dalam penelitian ini adalah semua siswa kelas V UPT. SD Negeri 01 Koto Laweh Kecamatan X Koto Kabupaten Tanah Datar yang berjumlah 19 siswa yang terdiri dari 9 siswa laki laki dan 10 siswa perempuan. Penelitian ini dilaksanakan dalam dua siklus. Pelaksanaan tiap siklus dilakukan dengan menggunakan metode pembelajaran matematika realistik dalam pembelajaran matematika materi pecahan dalam pemecahan masalah. Pengumpulan data dalam penelitian ini menggunakan metode tes dan observasi. Instrumen penelitian yang digunakan adalah berupa lembar soal uraian dan lembar observasi siswa dan guru. Teknik analisis data yang digunakan dalam penelitian ini dilakukan dengan teknik analisis data kualitatif dan analisis data kuantitatif. Analisis data kuantitatif dilakukan dengan menghitung persentase ketuntasan belajar siswa. Analisi data kualitatif dilakukan dengan mendeskripsikan kegiatan aktivitas siswa dan guru. Hasil penelitian menunjukkan bahwa hasil belajar siswa mengalami peningkatan dilihat dari aktivitas siswa yang mengalami 
peningkatan dari siklus I ke siklus II yang semula $67,11 \%$ menjadi $84,54 \%$. Hasil belajar siswa juga mengalami peningkatan dari siklus I sampai siklus II sehingga siswa dapat mencapai KKM sebesar 69. Sebelum adanya tindakan, siswa yang tuntas hanya 9 siswa atau sebesar $47,37 \%$ pada siklus I jumlah siswa yang tuntas meningkat menjadi 13 siswa atau sebesar $68,42 \%$ dan pada siklus II menunjukkan bahwa 17 siswa atau $89,47 \%$ sudah memenuhi KKM

Kata Kunci: PMR. Hasil Belajar, Matematika

\section{A. Pendahuluan}

Masalah utama pada pendidikan di Indonesia adalah rendahnya hasil belajar siswa di sekolah. Sementara perkembangan Ilmu Pengetahuan dan Teknologi (IPTEK) yang pesat saat ini membuat penguasaan pengetahuan matematika sangat perlu untuk dipahami dan dikuasai dengan baik oleh siswa. Dewasa ini dalam kehidupan seharihari manusia sudah lazim berpikir cepat, logis, serta mempergunakan teknologi yang lebih cepat dan praktis untuk memudahkan menyelesaikan pekerjaan. Berpikir cepat dan logis terdapat pada matematika. Tidak dapat dipungkiri bahwa tidak ada orang yang tidak memerlukan bantuan matematika dalam kehidupan sehari-hari.

Matematika sangat erat kaitanya dengan kegiatan sehari-hari manusia, baik dari hal yang sederhana sampai hal yang membutuhkan suatu pemikiran lebih. Matematika bukanlah suatu ilmu yang terisolasi dari kehidupan manusia, melainkan matematika justru muncul dari dan berguna untuk kehidupan sehari-hari kita. Suatu pengetahuan bukan sebagai objek yang terpisah melainkan sebagai suatu bentuk penerapan dalam kehidupan. Suatu ilmu pengetahuan akan sulit untuk kita terapkan jika ilmu pengetahuan tersebut tidak bermakna bagi kita. Kebermaknaan ilmu pengetahuan juga menjadi aspek utama dalam proses belajar. Proses belajar akan terjadi jika pengetahuan yang dipelajari bermakna bagi pembelajar (Freudental, 1991 dalam buku Ariyadi Wijaya, 2011:3).

Pembelajaran matematika selama ini dipandang sebagai alat yang siap pakai. Pandangan ini mendorong guru bersikap cenderung memberi tahu konsep dan cara menggunakannya. Pembelajaran matematika terfokus pada guru, sehingga siswa cenderung pasif. Guru yang mendominasi kegiatan pembelajaran di kelas. Selain itu masih terdapat metode konvensional yang diterapkan, membuat suasana pembelajaran di kelas monoton. Metode pembelajaran yang sering dilaksanakan, biasanya ceramah, guru yang menjelaskan materi pembelajaran, memberikan rumus dan siswa disuruh menghafal rumus tersebut tanpa mengetahui konsep rumus tersebut didapat dari mana. Pembelajaran yang demikian tidak kondusif sehingga membuat siswa menjadi sasaran pembelajaran yang pasif, dan hanya menerima konsep dari guru saja. Tidak semua siswa dapat menghafal dengan baik tanpa memahami suatu konsep. Hal ini berimplikasi pada hasil belajar siswa yang rendah atau tidak sesuai dengan target yang ingin dicapai dalam suatu proses pembelajaran.

Permasalahan serupa tentang rendahnya hasil belajar matematika juga terjadi pada siswa kelas V UPT. SD Negeri 01 Koto Laweh Kecamatan X Koto Kabupaten Tanah Datar. Berdasarkan pengamatan pada proses pembelajaran matematika di kelas V UPT. SD Negeri 01 Koto Laweh, diperoleh data mengenai hasil belajar yang rendah. Rendahnya hasil belajar ini dilihat dari hasil perolehan nilai Tes Kendali Mutu (TKM) untuk mata pelajaran matematika semester II tahun pelajaran 2019/2020, yang mana data tersebut dapat dilihat dalam tabel di bawah ini. 
Tabel Nilai Tes Kendali Mutu (TKM) Kelas V Semester II

Tahun Pelajaran 2019/2020

\begin{tabular}{|c|c|c|c|c|c|}
\hline \multirow[t]{2}{*}{ No } & \multirow{2}{*}{ Nama Peserta Didik } & \multirow[t]{2}{*}{ KKM } & \multirow[t]{2}{*}{ Nilai } & $\begin{array}{c}\text { Keteranga } \\
\mathrm{n}\end{array}$ & \\
\hline & & & & Tuntas & Belum Tuntas \\
\hline 1 & Adam Darmawan & 69 & 80 & $\sqrt{ }$ & \\
\hline 2 & Adryan Mulyono & 69 & 50 & & $\sqrt{ }$ \\
\hline 3 & Aisya Malsya & 69 & 80 & $\sqrt{ }$ & \\
\hline 4 & Aisya Putri & 69 & 60 & & $\sqrt{ }$ \\
\hline 5 & Amelia & 69 & 80 & $\sqrt{ }$ & \\
\hline 6 & Anifah & 69 & 60 & & $\sqrt{ }$ \\
\hline 7 & Aurel Saraswati & 69 & 70 & $\sqrt{ }$ & \\
\hline 8 & $\begin{array}{l}\text { Ferucha Maulana } \\
\text { Putri }\end{array}$ & 69 & 50 & & $\sqrt{ }$ \\
\hline 9 & Ibrahim Rahman A & 69 & 60 & & $\sqrt{ }$ \\
\hline 10 & Keisya Almagfira & 69 & 30 & & $\sqrt{ }$ \\
\hline 11 & M. Rizki & 69 & 80 & $\sqrt{ }$ & \\
\hline 12 & M. Wahyu Pratama & 69 & 50 & & $\sqrt{ }$ \\
\hline 13 & Muhammad Azin T & 69 & 70 & $\sqrt{ }$ & \\
\hline 14 & Nur Anisa & 69 & 60 & & $\sqrt{ }$ \\
\hline 15 & Nurzulia Azzahra & 69 & 80 & $\sqrt{ }$ & \\
\hline 16 & Raisya Nabila & 69 & 40 & & $\sqrt{ }$ \\
\hline 17 & Rasyid Fajri Elfira & 69 & 60 & & $\sqrt{ }$ \\
\hline 18 & Vathu Rahmah Aziz & 69 & 80 & $\sqrt{ }$ & \\
\hline 19 & Wahyu Al Fatha & 69 & 70 & $\sqrt{ }$ & \\
\hline Jumlah & 1210 & 9 & 10 & & \\
\hline $\begin{array}{l}\text { Nilai rata-rata } \\
\text { kelas }\end{array}$ & 63,68 & & & & \\
\hline Presentase & $47,37 \%$ & $52,63 \%$ & & & \\
\hline
\end{tabular}

Berdasarkan data tersebut dapat dilihat bahwa lebih dari $50 \%$ siswa belum mencapai Kriteria Ketuntasan Minimum (KKM), hal ini ditunjukan dengan nilai ratarata kelas yang masih di bawah KKM. Padahal jika dilihat dari penetapan KKM nya, KKM di UPT. SD Negeri 01 Koto Laweh itu masih tergolong sedang yaitu 69. Rendahnya hasil belajar matematika ini dipengaruhi oleh banyak faktor, antara lain proses pembelajarannya, siswa, guru, lingkungan kelas, maupun materinya sendiri. Dilihat dari proses pembelajarannya, yaitu pembelajaran masih bersifat konvensional, dimana guru kebanyakan menggunakan metode ceramah dan siswa diminta untuk mendengarkan dan menghafal rumus-rumus yang sudah ada. Padahal jika hanya 
dengan menghafal saja tanpa tahu konsepnya maka siswa akan lebih mudah untuk melupakan rumus tersebut. Alat peraga yang dimiliki sekolah juga masih terbatas.

Faktor siswa juga mempengaruhi rendahnya hasil belajar matematika. Siswa kelas V UPT. SD Negeri 01 Koto Laweh masih cenderung pasif saat mengikuti pembelajaran matematika. Siswa diminta untuk duduk diam memperhatikan penjelasan dari guru, sedangkan siswa yang duduk di bangku belakang asyik bermain sendiri atau berbicara dengan temannya. Guru juga berpengaruh terhadap hasil belajar anak. Guru hanya menggunakan metode ceramah, dan kurang inovatif dalam pembelajaran membuat siswa cepat bosan dan malas untuk belajar. Guru hanya terfokus untuk mengejar materi yang harus disampaikan kepada anak dan kurang memperhatikan kebermaknaan pengetahuan tersebut, sehingga kurang memberikan kesempatan pada anak untuk aktif menemukan sendiri konsepnya.

Kompetensi pelajaran matematika turut serta dalam menentukan hasil belajar. Kompetensi pelajaran matematika cukup luas, antara konsep yang satu dengan konsep yang lain saling berkesinambungan. Seorang siswa yang belum menguasai suatu konsep awal dengan tuntas, maka untuk tingkat selanjutnya akan sulit pula untuk mengikuti pelajaran tersebut. Sebagai contoh tentang konsep perkalian. Konsep perkalian sebagai penjumlahan berulang ada di kelas II, namun apabila seorang anak belum bisa memahami dan menguasai konsep ini dengan baik dan sudah naik ketingkat selanjutnya, maka anak akan semakin kesulitan sehingga akan membentuk persepsi dalam dirinya bahwa matematika itu pelajaran yang sulit.

Berdasarkan penjelasan tersebut, solusi untuk meningkatkan hasil belajar matematika siswa kelas V UPT. SD Negeri 01 Koto Laweh, Kecamatan X Koto adalah dengan menerapkan pendekatan matematika realistik. Suatu ilmu pengetahuan akan bermakna bagi pembelajar jika proses belajar melibatkan masalah realistik (Frendenthal, 1973 dalam buku Ariyadi Wijaya, 2011:3). Salah satu pendekatan pembelajaran yang menekankan pada kebermaknaan ilmu pengetahuan adalah Pendidikan Matematika Realistik (Realistic Mathematics Education). Strategi pembelajaran menggunakan pendekatan matematika realistik menekankan akan pentingnya konteks nyata yang dikenal siswa dan proses konstruksi pengetahuan matematika oleh siswa sendiri, dapat memberikan kesempatan siswa aktif dan kreatif. Siswa akan lebih mudah mengingat jika mereka membangun pengetahuan itu sendiri. Melalui konteks nyata siswa lebih mudah memahami suatu konsep, sehingga dengan pendekatan matematika realistik diharapkan siswa akan lebih memahami dan mengingat materi yang dipelajari, karena kebermaknaan ilmu pengetahuan juga menjadi aspek utama dalam proses belajar.

Dalam pendekatan matematika realistik, matematika disajikan sebagai suatu proses kegiatan manusia, bukan sebagai produk jadi. Unsur menemukan kembali amat penting. Bahan pelajaran disajikan melalui bahan ceritra yang sesuai lingkungan siswa (kontekstual), jadi realistis bagi siswa. Begitupun alat peraga sebaiknya juga berasal dari lingkungan siswa, sering digunakan bahan bekas jadi murah. Siswa dituntut aktif dan guru lebih banyak bertindak sebagai fasilitator. Dalam menyelesaikan soal ceritra, siswa diatur bekerja kelompok. Bahan ajar disiapkan sedemikian rupa sehingga cara penyelesaiannya bermacam-macam. Hal ini dilakukan untuk mendorong terjadinya diskusi antara kelompok. Ini merupakan bagian dari pelajaran demokrasi melalui matematika, jadi siswa belajar saling menghargai pendapat orang lain dan tidak bersikap benar sendiri. Matematika disajikan secara menarik, sering sambil bermain. Dalam Matematika Realistik siswa didorong mengembangkan pemikiran yang kritis, mempertanyakan banyak hal dan tidak \begin{tabular}{lll}
\hline EISSN 2657-0289 & Lembaga Penelitian dan Penerbitan Hasil Penelitian Ensiklopedia & 143
\end{tabular} 
begitu saja menerima suatu pendapat, siswa diajak untuk bepikir mandiri. Pembelajaran matematika realistik bertujuan supaya siswa dapat berpartisipasi aktif dalam mengkonstruksi pengetahuannya sendiri sehingga hasil belajar yang diperoleh dapat lebih bermakna dan hasilnya dapat meningkat.

Berdasarkan keunggulan-keunggulan pembelajaran matematika realistik di atas maka peneliti bermaksud menerapkan pendekatan pembelajaran tersebut untuk mengatasi masalah kesulitan hasil belajar siswa kelas V UPT. SD Negeri 01 Koto Laweh terkait pecahan dalam pemecahan masalah. Dalam penelitian ini peneliti mengambil judul "Peningkatan Hasil Belajar Matematika Dengan Pembelajaran Matematika Realistik (PMR) Untuk Siswa Kelas V UPT. SD Negeri 01 Koto Laweh”. Berdasarkan latar belakang masalah yang dijelaskan di atas, dapat diidentifikasikan masalah-masalah sebagai berikut: 1) Pembelajaran berpusat pada guru, sehingga guru lebih cenderung mendominasi pelajaran; 2) Guru lebih sering menggunakan metode ceramah, sehingga metode guru kurang bervariasi; 3) Siswa cenderung pasif dan kurang berminat mengikuti pembelajaran matematika; dan 4) Rendahnya hasil belajar matematika siswa.

\section{B. Metodologi Penelitian}

Penelitian ini termasuk jenis penelitian tindakan kelas kolaborasi. Menurut Suharsimi Arikunto, dkk (2007: 3) penelitian tindakan kelas merupakan suatu pencermatan terhadap kegiatan belajar berupa sebuah tindakan yang sengaja dimunculkan dan terjadi dalam sebuah kelas secara bersama. Tindakan tersebut diberikan oleh guru atau dengan arahan dari guru yang dilakukan oleh siswa.Jadi pengertian tindakan kelas adalah segala daya upaya yang dilakukan oleh guru berupa kegiatan penelitian tindakan atau arahan dengan tujuan dapat memperbaiki dan atau meningkatkan kualitas pembelajaran.Sedangkan yang dimaksud dengan kolaborasi yaitu karena penelitian ini merupakan kerja sama antara guru kelas dan peneliti. Guru berperan untuk melaksanakan proses pembelajaran dan peneliti bertindak sebagai pengamat (observer). Hal ini dengan tujuan agar pengamatan terhadap setiap tindakan yang dilakukan selama proses pembelajaran dapat teramati. Dalam penelitian ini, peneliti menemukan permasalahan dalam pembelajaran matematika pada siswa kelas $\mathrm{V}$ UPT. SD Negeri 01 Koto Laweh yaitu kurangnya pemahaman siswa dalam materi pecahan dalam pemecahan masalah. Peneliti bermaksud memecahkan masalah tersebut melalui penerapan pembelajaran matematika realistik. Penelitian merupakan usaha untuk mencari kebenaran atau merupakan suatu pencarian fakta. Kebenaran atau fakta yang dicari tersebut tentunya dibutuhkan suatu hal atau suatu keadaan. Suatu hal atau suatu keadaan ini disebut dengan subyek penelitian. Agar kebenaran mengenai subyek penelitian ini dapat diperoleh maka dibutuhkan sumber data. Sumber data sebagai subjek dalam penelitian ini adalah semua siswa kelas V UPT. SD Negeri 01 Koto Laweh Kecamatan X Koto Kabupaten Tanah Datar yang berjumlah 19 siswa yang terdiri dari 9 siswa laki - laki dan 10 siswa perempuan. Penelitian ini dilaksanakan di kelas V semester 2 UPT. SD Negeri 01 Koto Laweh. Lokasi SD ini terletak di tengah - tengah pemukiman penduduk. Lingkungan sekolah dalam keadaan baik, hal ini terlihat dari cara mengatur dan memelihara kelas, ruang guru, ruang kepala sekolah serta ruang - ruang lain sebagai penunjang sekolah. Suasana sekolah cukup nyaman dan mendukung untuk proses pembelajaran. Sebagian besar siswa berasal dari sekitar sekolah. 


\section{Hasil dan Pembahasan}

\section{Deskripsi Kondisi Awal}

Data awal diperoleh dari pre-test pra tindakan dilaksanakan yang diikuti oleh 19 siswa kelas V UPT. SD Negeri 01 Koto Laweh Kecamatan X Koto. Perolehan nilai Pre-Test hasil belajar Matematika pra tindakan pada siswa kelas V. Adapun data siswa yang memperoleh keberhasilan dapat diuraikan sebagai berikut:

Tabel Hasil Belajar Siswa Pra Siklus

\begin{tabular}{|c|c|c|c|c|c|}
\hline \multirow[t]{2}{*}{ No } & \multirow[b]{2}{*}{ Nama Peserta Didik } & \multirow[t]{2}{*}{ KKM } & \multirow[t]{2}{*}{ Nilai } & \multirow{2}{*}{$\begin{array}{c}\begin{array}{c}\text { Keteranga } \\
\mathrm{n}\end{array} \\
\text { Tuntas }\end{array}$} & \multirow[b]{2}{*}{$\begin{array}{l}\text { Belum } \\
\text { Tuntas }\end{array}$} \\
\hline & & & & & \\
\hline 1 & Adam Darmawan & 69 & 80 & $\sqrt{ }$ & \\
\hline 2 & Adryan Mulyono & 69 & 50 & & $\sqrt{ }$ \\
\hline 3 & Aisya Malsya & 69 & 80 & $\sqrt{ }$ & \\
\hline 4 & Aisya Putri & 69 & 60 & & $\sqrt{ }$ \\
\hline 5 & Amelia & 69 & 80 & $\sqrt{ }$ & \\
\hline 6 & Anifah & 69 & 60 & & $\sqrt{ }$ \\
\hline 7 & Aurel Saraswati & 69 & 70 & $\sqrt{ }$ & \\
\hline 8 & Ferucha Maulana Putri & 69 & 50 & & $\sqrt{ }$ \\
\hline 9 & Ibrahim Rahman A & 69 & 60 & & $\sqrt{ }$ \\
\hline 10 & Keisya Almagfira & 69 & 30 & & $\sqrt{ }$ \\
\hline 11 & M. Rizki & 69 & 80 & $\sqrt{ }$ & \\
\hline 12 & M. Wahyu Pratama & 69 & 50 & & $\sqrt{ }$ \\
\hline 13 & Muhammad Azin T & 69 & 70 & $\sqrt{ }$ & \\
\hline 14 & Nur Anisa & 69 & 60 & & $\sqrt{ }$ \\
\hline 15 & Nurzulia Azzahra & 69 & 80 & $\sqrt{ }$ & \\
\hline 16 & Raisya Nabila & 69 & 40 & & $\sqrt{ }$ \\
\hline 17 & Rasyid Fajri Elfira & 69 & 60 & & $\sqrt{ }$ \\
\hline 18 & Vathu Rahmah Aziz & 69 & 80 & $\sqrt{ }$ & \\
\hline 19 & Wahyu Al Fatha & 69 & 70 & $\sqrt{ }$ & \\
\hline Jumlah & 1210 & 9 & 10 & & \\
\hline $\begin{array}{l}\text { Nilai rata-rata } \\
\text { kelas }\end{array}$ & 63,68 & & & & \\
\hline Presentase & $47,37 \%$ & $52,63 \%$ & & & \\
\hline
\end{tabular}

Berdasarkan tabel diatas, terlihat bahwa 10 siswa kelas $\mathrm{V}$ belum mencapai nilai KKM yang ditetapkan sekolah, yakni 69. Adapun nilai rata-ratanya pun masih rendah, yakni 63,68. Hal ini menunjukkan bahwa pemahaman awal siswa terhadap materi mengubah pecahan ke bentuk persen dan desimal atau sebaliknya masih 
rendah. Untuk lebih jelasnya, berikut ini akan ditampilkan hasil pretes dalam bentuk diagram.

Selain itu, berdasarkan hasil observasi kelas, diketahui pula bahwa belum semua siswa kelas V memiliki motivasi belajar matematika yang tinggi. Hal ini terlihat dari sikap belajar mereka selama pembelajaran matematika. Berdasarkan hasil observasi yang dilakukan diketahui bahwa siswa pasif selama pembelajaran. Di samping itu, ketika mengerjakan soal, siswa terkadang justru mengobrol dengan temannya. Siswa juga harus ditunjuk terlebih dahulu untuk maju mengerjakan soal.

\section{Deskripsi Pelaksanaan Tindakan Siklus I}

Hasil belajar siswa dapat dilihat dari nilai tes evaluasi yang dilakukan pada setiap akhir siklus. Hasil tes siklus I disajikan melalui tabel di bawah ini :

TabelHasil Belajar Peserta Didik Siklus I

\begin{tabular}{|c|c|c|c|c|c|}
\hline \multirow[t]{2}{*}{ No } & \multirow[b]{2}{*}{ Nama Peserta Didik } & \multirow[t]{2}{*}{ KKM } & \multirow[t]{2}{*}{ Nilai } & \multirow{2}{*}{$\begin{array}{c}\text { Keteranga } \\
\text { n }\end{array}$} & \multirow[b]{2}{*}{$\begin{array}{l}\text { Belum } \\
\text { Tuntas }\end{array}$} \\
\hline & & & & & \\
\hline 1 & Adam Darmawan & 69 & 80 & $\sqrt{ }$ & \\
\hline 2 & Adryan Mulyono & 69 & 60 & & $\sqrt{ }$ \\
\hline 3 & Aisya Malsya & 69 & 80 & $\sqrt{ }$ & \\
\hline 4 & Aisya Putri & 69 & 70 & $\sqrt{ }$ & \\
\hline 5 & Amelia & 69 & 80 & $\sqrt{ }$ & \\
\hline 6 & Anifah & 69 & 60 & & $\sqrt{ }$ \\
\hline 7 & Aurel Saraswati & 69 & 70 & $\sqrt{ }$ & \\
\hline 8 & Ferucha Maulana Putri & 69 & 50 & & $\sqrt{ }$ \\
\hline 9 & Ibrahim Rahman A & 69 & 70 & $\sqrt{ }$ & \\
\hline 10 & Keisya Almagfira & 69 & 40 & & $\sqrt{ }$ \\
\hline 11 & M. Rizki & 69 & 90 & $\sqrt{ }$ & \\
\hline 12 & M. Wahyu Pratama & 69 & 60 & & $\sqrt{ }$ \\
\hline 13 & Muhammad Azin T & 69 & 80 & $\sqrt{ }$ & \\
\hline 14 & Nur Anisa & 69 & 70 & $\sqrt{ }$ & \\
\hline 15 & Nurzulia Azzahra & 69 & 80 & $\sqrt{ }$ & \\
\hline 16 & Raisya Nabila & 69 & 50 & & $\sqrt{ }$ \\
\hline 17 & Rasyid Fajri Elfira & 69 & 70 & $\sqrt{ }$ & \\
\hline 18 & Vathu Rahmah Aziz & 69 & 80 & $\sqrt{ }$ & \\
\hline 19 & Wahyu Al Fatha & 69 & 70 & $\sqrt{ }$ & \\
\hline Jumlah & 1310 & 13 & 6 & & \\
\hline $\begin{array}{l}\text { Nilai rata-rata } \\
\text { kelas }\end{array}$ & 68,95 & & & & \\
\hline
\end{tabular}

146 Lembaga Penelitian dan Penerbitan Hasil Penelitian Ensiklopedia 


\section{Presentase \\ $68,42 \%$ \\ $31,58 \%$}

Berdasarkan tabel di atas, diketahui bahwa peningkatan hasil belajar siswa masih belum memenuhi target yang telah ditetapkan oleh peneliti. Dari 19 siswa kelas V UPT. SD Negeri 01 Koto Laweh Kecamatan X Koto yang dijadikan objek pengambilan data, siswa yang dinyatakan tuntas atau telah memenuhi KKM ( nilai $\geq$ 69 ) sebanyak 13 orang siswa atau sebesar 68,42\% dengan nilai rata - rata 68,95. Dari uraian di atas dapat disimpulkan bahwa pengelolaan proses pembelajaran yang kurang optimal juga berpengaruh terhadap prestasi belajar siswa. Hal ini terlihat dari rata-rata prestasi belajar siswa yang belum tuntas atau belum mencapai Kriteria Ketuntasan Minimal (KKM) masih di bawah target yang ditetapkan peneliti yaitu $\geq$ 69 Meskipun rata - ratanya masih kurang dari nilai KKM. Tetapi ada peningkatan prestasi belajar sekitar $21,05 \%$ dibandingkan dengan hasil tes sebelum tindakan. Untuk itu diadakan siklus II untuk memeperbaiki prestasi belajar siswa pada pokok bahasan Menggunakan pecahan dalam pemecahan masalah.

\section{Deskripsi Pelaksanaan Tindakan Siklus II}

Pada tahap observasi, peneliti melakukan pengamatan terhadap hasil nilai tes siswa, aktivitas guru dan aktivitas siswa selama proses pembelajaran berlangsung. Hasil tes digunakan untuk melihat adanya peningkatan prestasi dari siklus II. Observasi guru digunakan untuk melihat proses pembelajaran yang diterapkan guru. Sedangkan observasi siswa digunakan untuk melihat aktivitas dan respon siswa terhadap metode dan media yang digunakan oleh guru.

Tabel Hasil Prestasi Belajar Peserta Didik Siklus II

\begin{tabular}{|c|c|c|c|c|c|}
\hline \multirow[b]{2}{*}{ No } & \multirow[b]{2}{*}{$\begin{array}{c}\text { Nama Peserta } \\
\text { Didik }\end{array}$} & \multirow{2}{*}{ KKM } & \multirow[b]{2}{*}{ Nilai } & Keterangan & \multirow[b]{2}{*}{$\begin{array}{l}\text { Belum } \\
\text { Tuntas }\end{array}$} \\
\hline & & & & Tuntas & \\
\hline 1 & Adam Darmawan & 69 & 100 & $\sqrt{ }$ & \\
\hline 2 & Adryan Mulyono & 69 & 70 & $\sqrt{ }$ & \\
\hline 3 & Aisya Malsya & 69 & 90 & $\sqrt{ }$ & \\
\hline 4 & Aisya Putri & 69 & 80 & $\sqrt{ }$ & \\
\hline 5 & Amelia & 69 & 80 & $\sqrt{ }$ & \\
\hline 6 & Anifah & 69 & 70 & $\sqrt{ }$ & \\
\hline 7 & Aurel Saraswati & 69 & 70 & $\sqrt{ }$ & \\
\hline 8 & $\begin{array}{l}\text { Ferucha Maulana } \\
\text { Putri }\end{array}$ & 69 & 70 & $\sqrt{ }$ & \\
\hline 9 & $\begin{array}{l}\text { Ibrahim Rahman } \\
\text { A }\end{array}$ & 69 & 70 & $\sqrt{ }$ & \\
\hline 10 & Keisya Almagfira & 69 & 50 & & $\sqrt{ }$ \\
\hline 11 & M. Rizki & 69 & 100 & $\sqrt{ }$ & \\
\hline 12 & $\begin{array}{l}\text { M. Wahyu } \\
\text { Pratama }\end{array}$ & 69 & 70 & $\sqrt{ }$ & \\
\hline 13 & Muhammad Azin & 69 & 80 & $\sqrt{ }$ & \\
\hline
\end{tabular}




\begin{tabular}{|c|l|c|c|c|c|}
\hline & T & & & & \\
\hline 14 & Nur Anisa & 69 & 90 & $\sqrt{ }$ & \\
\hline 15 & Nurzulia Azzahra & 69 & 80 & $\sqrt{ }$ & \\
\hline 16 & Raisya Nabila & 69 & 60 & & $\sqrt{ }$ \\
\hline 17 & Rasyid Fajri Elfira & 69 & 70 & $\sqrt{ }$ & \\
\hline 18 & $\begin{array}{l}\text { Vathu Rahmah } \\
\text { Aziz }\end{array}$ & 69 & 100 & $\sqrt{ }$ & \\
\hline 19 & Wahyu Al Fatha & 69 & 80 & $\sqrt{ }$ & \\
\hline Jumlah & \multicolumn{1}{|c|}{1480} & 17 & 2 & & \\
\hline $\begin{array}{l}\text { Nilai rata-rata } \\
\text { kelas }\end{array}$ & 77,89 & & & & \\
\hline Presentase & $89,47 \%$ & $10,53 \%$ & & & \\
\hline
\end{tabular}

Berdasarkan tabel di atas, diketahui bahwa siswa yang telah memenuhi KKM ( nilai $\geq 69$ ) berjumlah 17 siswa dari 19 siswa Artinya sudah 89,47\% anak yang sudah mencapai KKM yang telah ditentukan dengan nilai rata - rata 77,89 sehingga dapat dikatakan bahwa penggunaan metode pembelajaran matematika realistik dapat meningkatkan prestasi belajar siswa tentang materi Menggunakan pecahan dalam pemecahan masalah.

\section{Pembahasan}

Hasil penelitian dari pelaksanaan siklus I dan siklus II adalah sebagai berikut: Dari penjabaran di atas aktivitas siswa dan guru pada siklus I dan siklus II terdapat peningkatan aktivitas siswa dan guru selama proses pembelajaran. Peningkatan aktivitas guru dan siswa selama proses pembelajaran dapat dilihat pada diagram berikut ini: Berdasarkan data tersebut, pengelolaan pembelajaran yang diterapkan oleh guru berpengaruh terhadap aktivitas siswa dalam mengikuti peroses pembelajaran. Pada siklus I, pengelolaan pembelajaran yang dilakukan oleh guru kurang optimal terbukti persentase keefektifan guru dalam mengelola pembelajaran hanya sebesar $63,54 \%$. Hal ini berdampak pada persentase aktivitas siswa dalam mengikuti pembelajaran yaitu sebesar $67,11 \%$. Pada siklus II terdapat kenaikan persentase pengelolaan proses pembelajaran yang dilakukan oleh guru sebesar 30,21\%. dari $63,54 \%$ menjadi $93,75 \%$. Keikutsertaaan siswa dalam proses pembelajaran juga mengalami kenaikan sebesar $17,43 \%$ dari $67,11 \%$ menjadi $84,54 \%$. Kenaikan aktivitas tersebut disebabkan karena pada siklus II lebih ditekankan metode matematika realistik yang disertai dengan permainan.

Perencanaan dan pengelolaan proses pembelajaran yang dilakukan oleh guru pada akhirnya berimplikasi langsung terhadap pencapaian prestasi belajar yang diperoleh siswa. Perencanaan dan pengelolaan proses pembelajaran yang baik dengan metode matematika realistik terbukti dapat meningkatkan prestasi belajar siswa di setiap siklus.Peningkatan hasil belajar ini terlihat pada tabel di bawah ini:

Tabel Hasil Nilai Prasiklus Sampai Siklus II

\begin{tabular}{|c|l|c|c|c|}
\hline No & Nama Peserta Didik & Pra Siklus & Siklus I & Siklus II \\
\hline 1 & Adam Darmawan & 80 & 80 & 100 \\
\hline
\end{tabular}




\begin{tabular}{|c|c|c|c|c|}
\hline 2 & Adryan Mulyono & 50 & 60 & 70 \\
\hline 3 & Aisya Malsya & 80 & 80 & 90 \\
\hline 4 & Aisya Putri & 60 & 70 & 80 \\
\hline 5 & Amelia & 80 & 80 & 80 \\
\hline 6 & Anifah & 60 & 60 & 70 \\
\hline 7 & Aurel Saraswati & 70 & 70 & 70 \\
\hline 8 & Ferucha Maulana Putri & 50 & 50 & 70 \\
\hline 9 & Ibrahim Rahman A & 60 & 70 & 70 \\
\hline 10 & Keisya Almagfira & 30 & 40 & 50 \\
\hline 11 & M. Rizki & 80 & 90 & 100 \\
\hline 12 & M. Wahyu Pratama & 50 & 60 & 70 \\
\hline 13 & Muhammad Azin T & 70 & 80 & 80 \\
\hline 14 & Nur Anisa & 60 & 70 & 90 \\
\hline 15 & Nurzulia Azzahra & 80 & 80 & 80 \\
\hline 16 & Raisya Nabila & 40 & 50 & 60 \\
\hline 17 & Rasyid Fajri Elfira & 60 & 70 & 70 \\
\hline 18 & Vathu Rahmah Aziz & 80 & 80 & 100 \\
\hline 19 & Wahyu Al Fatha & 70 & 70 & 80 \\
\hline Jumlah & 1210 & 1310 & 1480 & \\
\hline Nilai Rata- Rata siswa & 63.68 & 68.95 & 77.89 & \\
\hline Persentase Ketuntasan & $47,37 \%$ & $68,42 \%$ & $89,47 \%$ & \\
\hline
\end{tabular}

Berdasarkan tabel di atas, peningkatan prestasi belajar siswa sudah mencapai KKM ( nilai > 69) dapat dilihat pada diagram di bawah ini: Hal ini dapat dilihat pada pra siklus ( sebelum tindakan ) jumlah siswa yang memenuhi KKM hanya 9 orang siswa atau sebesar $47,37 \%$ sedangkan yang belum memenuhi KKM 10 orang siswa atau sebesar 52,63\%. Siklus I menyatakan bahwa jumlah siswa yang memenuhi KKM sebanyak 13 orang siswa atau sebesar $68,42 \%$ sedangkan yang belum memenuhi KKM 6 orang siswa atau sebesar $31,58 \%$. Kemudian pada siklus II yang memenuhi KKM adalah 17 orang siswa, atau sebesar 89,47\% siswa telah memenuhi KKM.

Berdasarkan data yang diperoleh dari siklus I dan II dapat disimpulkan bahwa terdapat kenaikan prestasi belajar siswa pada setiap siklusnya. Hal ini membuktikan bahwa penggunaan metode pembelajaran matematika realistik dapat meningkatkan prestasi belajar siswa pada pokok bahasan Menggunakan pecahan dalam pemecahan masalah. Berdasarkan data-data yang diperoleh dalam penelitian dapat disimpulkan bahwa hasil belajar matematika siswa kelas V UPT. SD Negeri 01 Koto Laweh Kecamatan X Koto Kabupaten Tanah Datar pada materi menggunakan pecahan dalam pemecahan masalah melalui penerapan Pendekatan Matematika Realistik mengalami peningkatan. 


\section{Penutup}

Berdasarkan data yang diperoleh melalui Penelitian Tindakan Kelas tentang perbandingan dan skala menggunakan penerapan pembelajaran matematika realistik dapat ditarik kesimpulan bahwa penerapan pembelajaran matematika realistik dapat meningkatkan kemampuan menggunakan pecahan dalam pemecahan masalah bagi siswa kelas V UPT. SD Negeri 01 Koto Laweh Kecamatan X Koto Kabupaten Tanah Datar. Hal ini dapat dilihat dari aktivitas siswa yang mengalami peningkatan dari siklus I ke siklus II yang semula $67,11 \%$ menjadi $84,54 \%$. Hasil belajar siswa juga mengalami peningkatan dari siklus I sampai siklus II sehingga siswa dapat mencapai KKM sebesar 69. Sebelum adanya tindakan, siswa yang tuntas hanya 9 siswa atau sebesar $47,37 \%$ pada siklus I jumlah siswa yang tuntas meningkat menjadi 13 siswa atau sebesar $68,42 \%$ dan pada siklus II menunjukkan bahwa 17 siswa atau $89,47 \%$ sudah memenuhi KKM.

\section{Daftar Pustaka}

Antonius Cahya Prihandoko. (2006). Pemahaman dan Penyajian Konsep Matematika secara Benar dan Menarik. Jakarta : Depdiknas Dirjen Dikti Direktorat Ketenagaan

Asmin. (2002). Implementasi Pembelajaran Matematika Realistik (PMR),dan Kendala yang Muncul di Lapangan.Medan:MIPA http://www.depdiknas.go.id/jurnal/44/asman.htm.

Daitin Tarigan.(2008).Pembelajaran Matematika Realistik.Jakarta : Dirjen Dikti

Depdikbud.(1991).Kamus Besar Bahasa Indonesia. Jakarta : Balai Pustaka

Depdiknas.(2006). Permendiknas Nomor 22 Tahun 2006 Tentang Standar Isi

Sekolah Menengah Atas. Jakarta: Depdiknas

Fadjar Shadiq.(2010).Apa dan Mengapa Matematika itu Penting.Diakses dari : http://blogger.kebumen.info/docs/contoh-artikel-peran-matematika-dalamkehidupan-sehari-hari.php.

Hadi Hasyim Muttaqim.(2009). Tujuan Pembelajaran Matematika. Diakses dari: http://muttaqinhasyim.wordpress.com

Herman Hudojo.(1990). Strategi Belajar Mengajar. Malang: IKIP

Herman Hudojo, \& Akbar Sutawidjaja.(1997). Matematika. Jakarta : Bagian Proyek Pengembangan PGSD Dirjen Dikti Depdikbud

Irwan Rozani. (2002). Realistic Mathematic Education atau Pembelajaran Matematika Realistik. http://ironerozanie.wordpress.com

Nawawi Hadari. (1991). Pengaruh Hubungan Manusia di Kalangan Murid Terhada Prestasi Belajar di Sekolah Dasar. Jakarta:Depdikbud.

Suharsimi Arikunto.(2002). Manajemen Penelitian. Jakarta: Rineka Cipta

Suharsimi Arikunto, Supardi, \& Sugihartono.(2007).Penelitian Tindakan Kelas. Jakarta: Bumi Aksara

Suherman. et al.(2003). Strategi Pembelajaran Matematika Kontemporer.

Bandung: FMIPA UPI

Sutrisno Hadi. (2004).Statistika. Yogyakarta 